\title{
移動液膜自由界面のメニスカス不安定性*
}

\author{
古曰日出男*1, 矢田敏夫*1
}

\section{A Meniscus Instability for the Moving Free Surface of Thin Liquid Film}

\author{
Hideo KOGUCHI and Toshio YADA
}

\begin{abstract}
The authors studied the instability of the meniscus of a viscous liquid between two closely spaced tilted plates when they are separated from each other in the normal direction of the plates. The instability has a close relation with that of the creeping flow in a Hele Shaw cell and is caused by viscous forces In the present paper, a local capillary number is newly defined by the local velocity of the leading meniscus the instability criterion is theoretically deduced. The simple criterion for the instability concerned with the local capillary number and the nondimen sional wave number for perturbation on the meniscus agrees well the experimental results. The theoretical formulation of the disturbances of the free surface predicts fairly well the experimental wavelength.
\end{abstract}

Key Words: Viscous Flow, Stability, Meniscus, Linear Instability Theory, Hele Shaw Cell, Neutral Stability, Wave Number, Local Capillary Number

\section{1. 緒言}

著者らは，粘性流体存閏に入れな倾斜斗板在引離

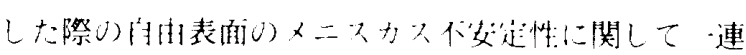

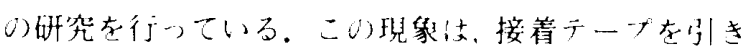

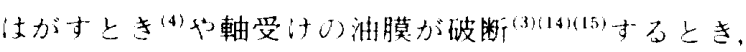

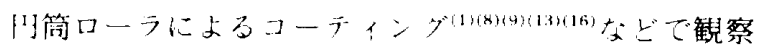

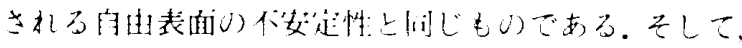
二れし，流机仗基本的に㳉羊い粘性流机である Hele

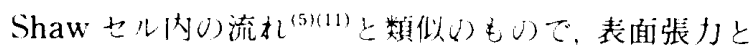

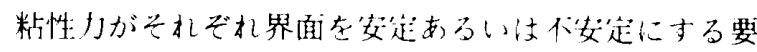
肉である。著者的は，流体を法さむ板を引き離挴際り

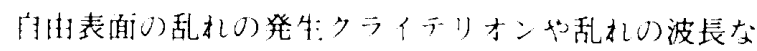

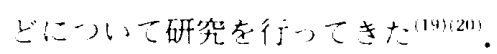

前報 ${ }^{(19)}$ で沈，板を引き離寸速度で修湴末ャビラり数

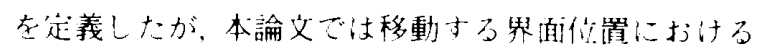
移動速度在朋いた后所キャビ：数在新たに提案守 る.こひ同所キャビラリ数㳉, Hele Shaw セルなよ゙ひ

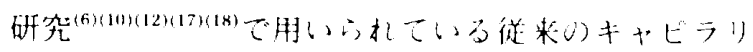
数り走義ひ自然な抬張になっており，将来を机らり研

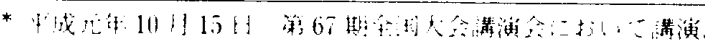

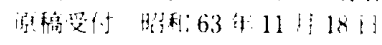

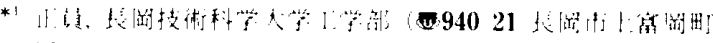
160313
究結果上本研究ひ結果老比較することができると考え 記る。本報では，その局所キャビラリ数と乱れの打

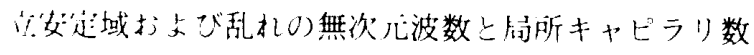
とし関俰導き，契験結果と比較する。

\section{2. メニスカス不安定の理論解析}

基本解の誘導は，解報(19)(20)で詳緗に述べてあるの で、ここではそい概略を説明寸るにとどぬる。

\section{$2 \cdot 1$ 薄い液膜内の流れ（摂動がない場合）解析} する液膜し形状と唑標系を刹1に示寸。ただし，寸き

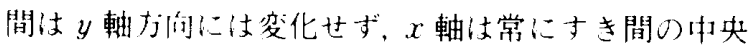

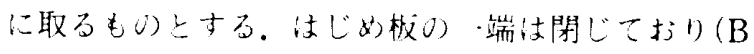
端)，他端法初期与間 $h_{0}$ 江開いている(A 端)上す

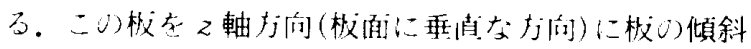

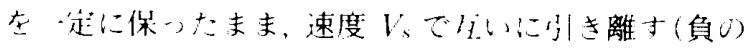

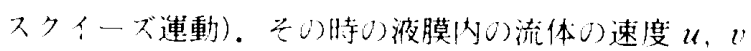

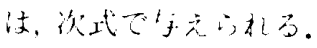

$$
\begin{aligned}
& u=\begin{array}{cc}
1 & \partial p \\
2 \Downarrow & \partial x
\end{array}\left(\begin{array}{cc}
z^{2} & h^{2} \\
& 4
\end{array}\right) \\
& v=\begin{array}{cc}
1 & \partial p \\
2 \mu & \partial y
\end{array}\left(\begin{array}{cc}
z^{2} & h^{2} \\
& 4
\end{array}\right) .
\end{aligned}
$$

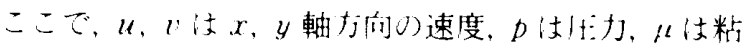

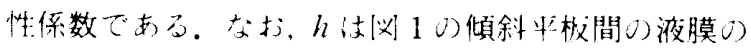


厚さで， $\alpha=V_{s} t / h_{0}\left(t\right.$ 时時間)と扮计济， $h=h_{0}(1+a$ - $x(L)$ で表される。ここで，Lは $x$ 軸方向の板の長さ でする(A端とB端ひ長き)。

式(1)と連続の式から，次の庄力の支配方程式が得 $\therefore$ 市。

$$
\frac{\partial}{\partial x}\left(h^{3} \frac{\partial p}{\partial x}\right)+h^{3} \partial^{2} p=12 \mu V^{2}
$$

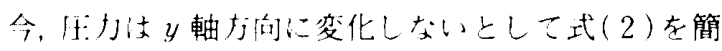

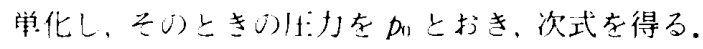

$$
\frac{d}{d x}\left(h^{3} \frac{d p_{0}}{d x}\right)=12 \mu V_{s}
$$

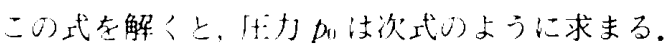

$$
\begin{aligned}
& p_{01}(x)=\frac{6 \mu V_{s} L^{2}(1+a)}{h_{11} h^{2}}-\frac{12 \mu V_{s} L^{2}}{h_{11}^{2} h} \\
& +\frac{C_{1} L}{2 h_{0} h^{2}}+C_{2}
\end{aligned}
$$

メ二ス力スの曲率米涤を液膜す厚さhの $1 / 2$ とし て境界条件に表㑲張力 $T$ 在考慮することに上り， $C_{1}$ 上 $C_{2}$ 汁次式の上うに求まる。

$$
\begin{aligned}
C_{1}= & \begin{array}{l}
4 T h_{1} h_{1} h_{2} \\
I\left(h_{1}+h_{2}\right)
\end{array}-12 \mu V_{s} I(1+\alpha) \\
+ & \begin{aligned}
24 \ell^{\prime} V_{s} I h_{1} h_{2} \\
h_{11}\left(h_{1}+h_{2}\right)
\end{aligned} \\
C_{2}= & p_{a}-\frac{2 T}{h_{1}+h_{2}}+\begin{array}{c}
12 \mu V_{s} I_{2}^{2} \\
h_{11}{ }^{2}\left(h_{1}+h_{2}\right)
\end{array}
\end{aligned}
$$

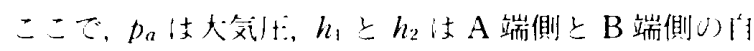

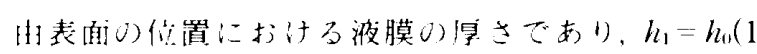
$\left.+a-x_{1} / L\right), h_{2}=h_{1}\left(1+\alpha-x_{2} / L\right) て ゙$ 表せら机る。なお，

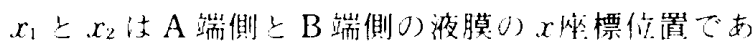

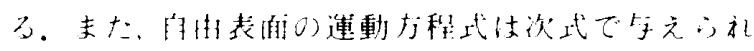
$3^{(20) !}$.

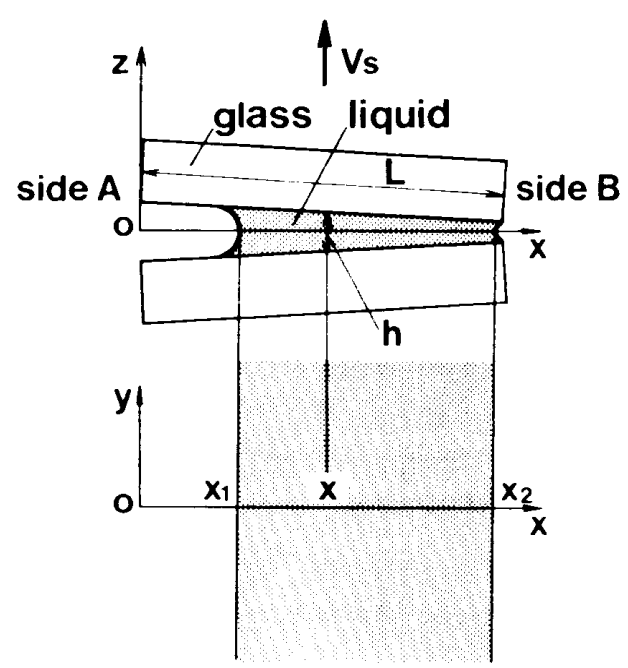

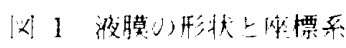

$$
\begin{aligned}
& \frac{d x_{1}}{d t}=-\frac{V_{s}}{h_{1}} x_{1}-\frac{C_{1}}{12 \mu h_{1}} \\
& \frac{d x_{2}}{d t}=-\frac{V_{s}}{h_{2}} x_{2}-\frac{C_{1}}{12 \mu h_{2}}
\end{aligned}
$$

$2 \cdot 2$ メニスカスの捸動解析 自由表面に摄動を ‘文大場合の解析についても前報で報告したが、ここ で注 Park と Homsyら(6)の Hele-Shaw七ルの界面 ひ境界条件の研究を参考にして、本研究の境界条件在 ‘文ることに守る。

ここでは、与えた挍動が成長する条件について詳細

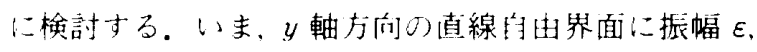
波坛えの掑動が卞えられたとする。この時，A 端側の 界面け $x-y$ 面上，形状は次式で表されるとする。

$$
S_{1}\left(x_{1}, y, t\right)=x_{1}(t)+\varepsilon e^{w t} \cos (k y)
$$

この式で $x_{1}$ 汁直線状の界面のある俈置， $t$ :時間， $k$ 汁波数で $2 \pi / \lambda$ たるる。

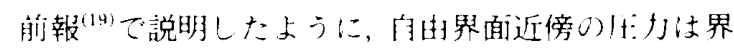

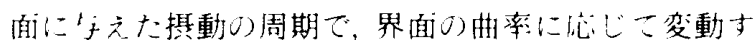

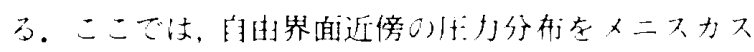

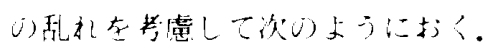

$$
p(x, y, t)=p_{n}(x)+\varepsilon\left(i(x) e^{\omega t} \cos (k y) \cdots \cdots(8)\right.
$$

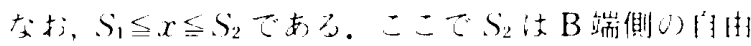

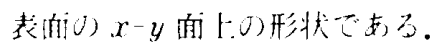

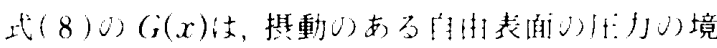

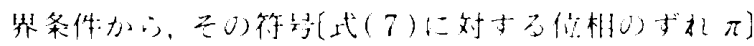

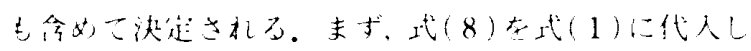

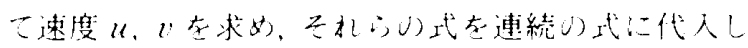

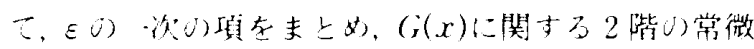

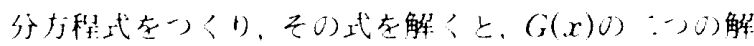
が無限級数り形で求まる。ところで、A端側り乱机

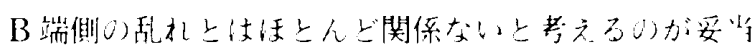
でまり、きらに、些験でもA 端側が琴れても

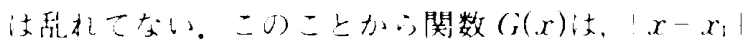

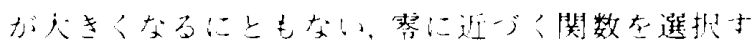

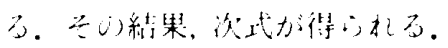

$$
\left(i(x)=a_{1} \sum_{m}^{\infty} 4^{m}(m+1) ! m !\right.
$$

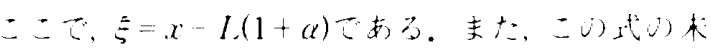

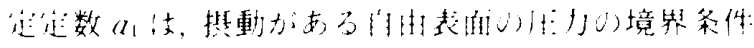

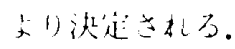

$2 \cdot 3$ 圧力の境界条件 ここでは, Park 上Homsy $\therefore$;

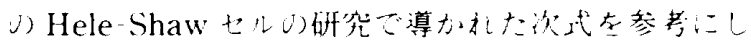

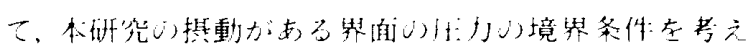
z.

$$
p_{a}=p_{h_{1}}^{2 T}\left(1+3.8\left(a^{23}+\cdots\right)\right.
$$




$$
R\left\{\begin{array}{l}
\pi \\
4
\end{array}+0\left(C a^{2 / 3}\right)\right\}
$$

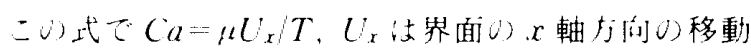

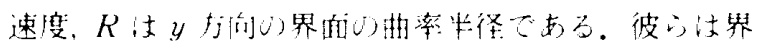

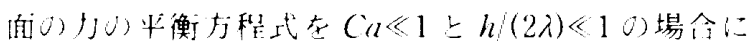

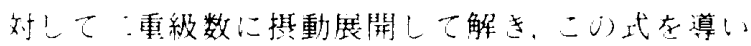
t.

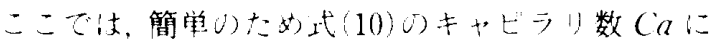

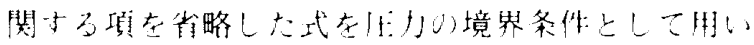

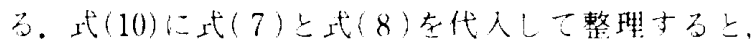

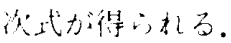

$$
\begin{aligned}
& p_{a}-p_{11}\left(S_{1}\right)-\varepsilon G\left(S_{1}\right) \epsilon^{w t} \cos (k y) \\
& \quad-\cdots T\left\{\frac{2}{h\left(S_{1}\right)}-\left.\varepsilon k^{2} \pi{ }_{4}{ }^{w i t} \cos (k y)\right|_{x} \cdot s\right\}
\end{aligned}
$$

こひ式在 Taylor 開して、モU次U項をままる

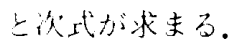

$$
\left(i\left(x_{1}\right)=-\left.\frac{d p_{0}}{d x}\right|_{x_{x}}+T\left(\begin{array}{ccc}
2 & d h_{1} & -k^{2} \\
h_{1}^{2} & d x & \\
4
\end{array}\right)\right.
$$

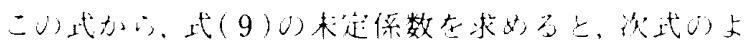
汇なる。

$$
\left.\left.\left.a_{1}-\begin{array}{c}
-1 \\
I_{1}\left(x_{1}\right)
\end{array}\right\} \begin{array}{c}
12 \mu V_{h} r_{1}+C_{1}+T\left(\begin{array}{c}
2 h_{11} \\
h_{1}{ }^{2}{ }^{2} L
\end{array}+k^{2} \pi\right. \\
h_{1}
\end{array}\right)\right\}
$$

ここで

$$
\begin{aligned}
& I_{1}\left(x_{1}\right)=\sum_{m+11}^{\infty} \begin{array}{c}
k^{m}(m+1) ! \\
\xi_{1}^{2 m}
\end{array} \\
& \xi_{1}=x_{1} \quad L(1+\alpha)
\end{aligned}
$$

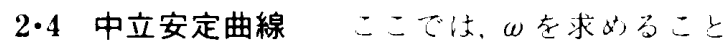

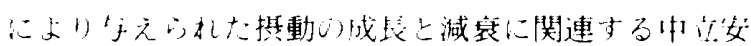

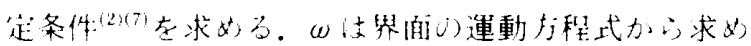

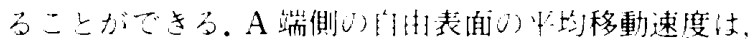
式(1)在乙て積行し，液膜闹さで制ることにより次式 山上得的机。

$$
u=-\begin{array}{cc}
h^{2} & d p \\
12 \mu & d x
\end{array}
$$

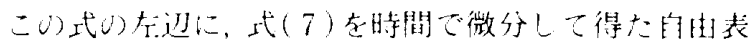
面し)移動速度を。有过に式(7)上式（8）在代人与る上 次式が得的水る。

$$
\begin{aligned}
& \frac{d x_{1}}{d t}+\varepsilon \omega \epsilon^{\omega t} \cos k y=\cdots \frac{1}{12 \mu_{\ell}}\left[h^{2}\left(x_{1}+\varepsilon e^{\omega t} \cos k y\right)\right. \\
& \left.\quad \times\left\{\frac{d p_{0}}{d x}+\varepsilon \frac{d G}{d x} \epsilon^{\omega t} \cos (k y)\right\}\right] \ldots \ldots \ldots \cdots \cdots(16)
\end{aligned}
$$

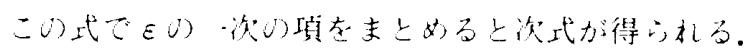

$$
\omega=-\frac{1}{12 \mu}\left[h_{1}^{2} d\left(x+\left.\frac{d}{d x}\left(h^{2} d p_{0}\right)\right|_{x x_{1}}\right]\right.
$$

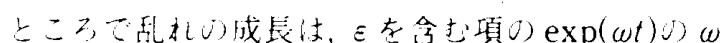

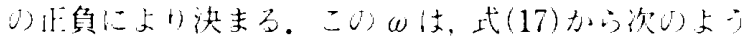
红求就的。

$$
\begin{aligned}
& \omega=\frac{T h_{1}{ }^{2}}{12 \mu{ }^{1}}\left[C a_{1} 12\left(\begin{array}{cc}
I_{2} L \\
I_{1}
\end{array}-\begin{array}{ll}
h_{0} \\
h_{1}
\end{array}+\begin{array}{cc}
V_{s} & I \\
H_{x} & h_{1}
\end{array}\right)\right. \\
& \left.\left(\begin{array}{c}
2 h_{1} L \\
h_{1}^{2}
\end{array}+\begin{array}{c}
\pi \\
4
\end{array} k^{2} L^{2}\right) \begin{array}{c}
I_{2} L \\
I_{1}
\end{array}\right]
\end{aligned}
$$

ここで

$$
I_{2}\left(x_{1}\right)=\sum_{m}^{\infty} 2^{2 m} 1(m+1) !(m-1) !
$$

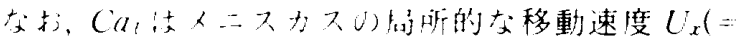

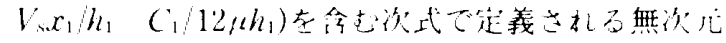

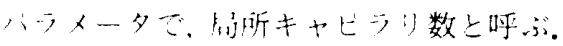

$$
C a_{i}=\frac{\mu V_{x}}{T}\left(\begin{array}{l}
1 \\
h_{1}
\end{array}\right)^{2}
$$

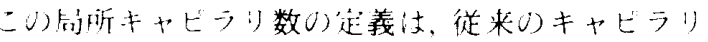

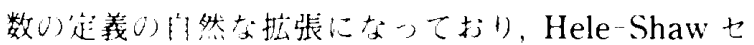

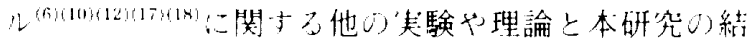

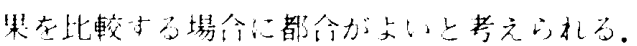

式(18)法， $\omega$ 江刘与る(

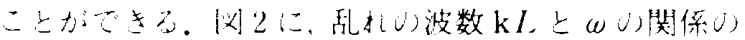

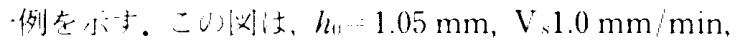
$\mu=10.7 \mathrm{~Pa} \cdot \mathrm{s}, T-21.2 \mathrm{~m} \cdot \mathrm{N} / \mathrm{m}, L=60 \mathrm{~mm} U$ )条件:

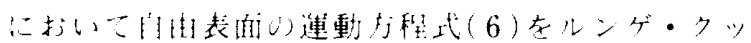

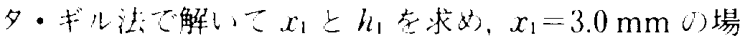
合に奶して局所キやビラり数を $100,500,1000$,

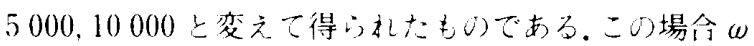

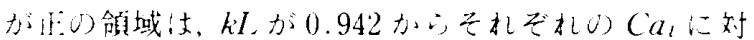
して25.1，75.4，94.2，251，377までし範用であ一た。

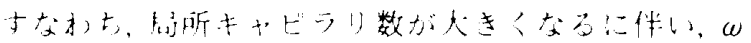

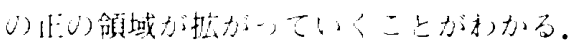

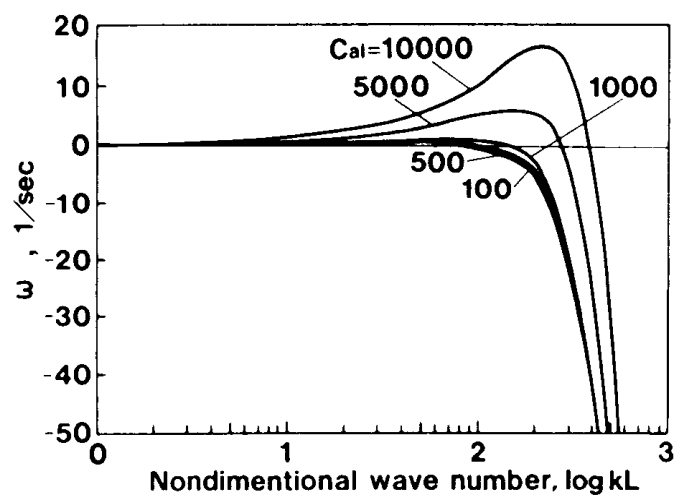

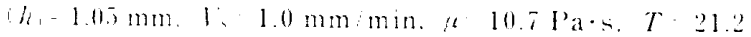

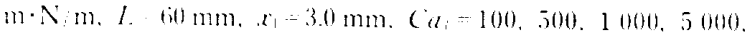
10 (1)

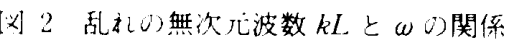


一般に，乱机が成長する場合は，時間とともに乱れ が大きくならなければならないので，いは正でなけれ ばならない.そして，その限界は式(18)から $\omega=0$ と置 いて得ら机，その結果は式(21)の上うに得られる。

$$
\mathrm{C} a_{l}=\mathrm{C} a_{\mathrm{stab}}
$$

ここで，C $a_{\text {stab }}$ は次式で与えられる。

$$
C a_{\text {stab }}=\frac{1}{12} \frac{\frac{\pi}{4} k^{2} L^{2}+\frac{2 h_{0} L}{h_{1}^{2}}}{1+\left(\frac{V_{s} L}{U_{x} h_{1}}-\frac{h_{0}}{h_{1}}\right) \frac{I_{1}}{I_{2} L}}
$$

式(21)を満足する曲線が中立安定曲線であり，Cal $<C a_{\text {stab }}$ の領域が不安定領域である。図 3 沖, 条件が $V_{s}=0.05 \mathrm{~mm} / \mathrm{min}, h_{0}=0.3 \mathrm{~mm}, \mu=10.7 \mathrm{~Pa} \cdot \mathrm{s}, T=$ $21.2 \mathrm{~m} \cdot \mathrm{N} / \mathrm{m}$ の場合で，前述したように式（6）を解い て液膜自由表面の位置を求め，その位置 $x_{1}=0,1,3$, $5,7 \mathrm{~mm} に お け る 中$ 立安定曲線の一例である。この図 より，液膜の移動に伴って不安定領域が $C a$ ，の大きい ほうに移動していくこと, 乱れの発生に臨界局所キャ ピラリ数があり，これに対応して臨界波長を与える無 次元臨界波数 $K_{\text {orit }} L$ があることがわかる.

次に，板の長さ $L$ ，変之た場合の中立安定曲線の 変化について示す. 図 4 は, $T=21.2 \mathrm{~m} \cdot \mathrm{N} / \mathrm{m}, \mu=1.02$ $\mathrm{Pa} \cdot \mathrm{s}, \quad V_{s}=1.0 \mathrm{~mm} / \mathrm{min}, h_{0}=0.5 \mathrm{~mm}, x_{1}=1.0 \mathrm{~mm} \sigma$ 場合で， $L=10,20,40,60,80,100,150,200,250$, $300 \mathrm{~mm}$ と変えて得的れた中立安定曲線の一一例であ る.この場合， $L$ を変えることは板の傾斜角 $h_{0} /(2 L)$ を変えることを意味する，この図から，板の傾斜角が 小さくなるに伴い，臨界局所キャビラり数が大きくな つていくことがわかる。さらに，板の初期すき間 $h_{0}$ を 変之た場合の中立安定曲線の变化を図 5 に示寸。この 図泣 $x_{1}=1.0 \mathrm{~mm}, T=21.2 \mathrm{~m} \cdot \mathrm{N} / \mathrm{m}, \mu=1.02 \mathrm{~Pa} \cdot \mathrm{s}$, $V_{\mathrm{s}}=1.0 \mathrm{~mm} / \mathrm{min}, L=60 \mathrm{~mm}$ に打いて $h_{0}$ を $0.01 \sim 1.0 \mathrm{~mm}$ まで変えて得られたものである。この 図で $h_{0}$ が小さくなるに伴い，臨界局所キャピラリ数 と臨界波数がともに大きくなっていくことがわかる。 $L$ と $h_{0}$ を変之た場合の臨界局所キャビラリ数の変化 は，拈よそ次式から推定することができる，寸なわち， 簡単のため自由表面の位置が $x_{1}=0$ の近傍にあるとす る。一般に，無次元波数 $k L$ が小さくなると $I_{1} / I_{2} L$ は 小きくなり，その結果式(21)は次式のように簡単にな る.

$$
C a_{l}=\frac{h_{0} L}{6 h_{1}^{2}}
$$

あるいは、

$$
C a=-\frac{h_{0}}{6}
$$

式(24)は，Ca= $\mu U_{x} / T$ が与えられたとき，その值が

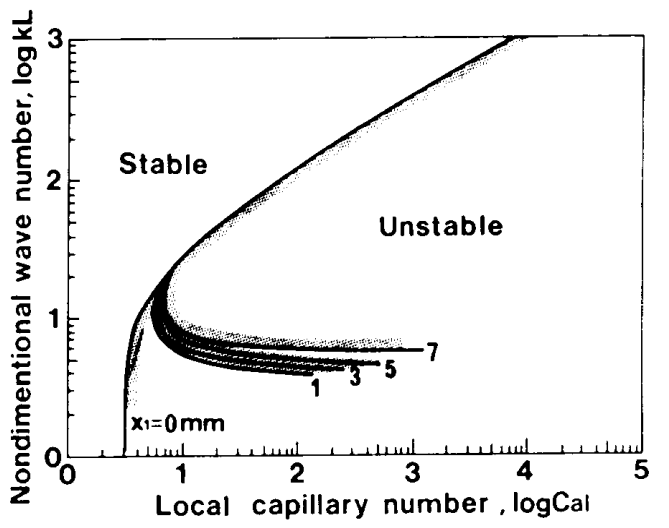

$V=0.05 \mathrm{~mm} / \mathrm{min}, \quad h=0.3 \mathrm{~mm}, \quad \mu=10.7 \mathrm{~Pa} \cdot \mathrm{s} . T=21.2$ $\mathrm{m} \cdot \mathrm{N} / \mathrm{m}, x,=0.3,5.7 \mathrm{~mm})$

図 3 自由表面移動による中立安定曲線と無次元波数とひ 関倸心変化

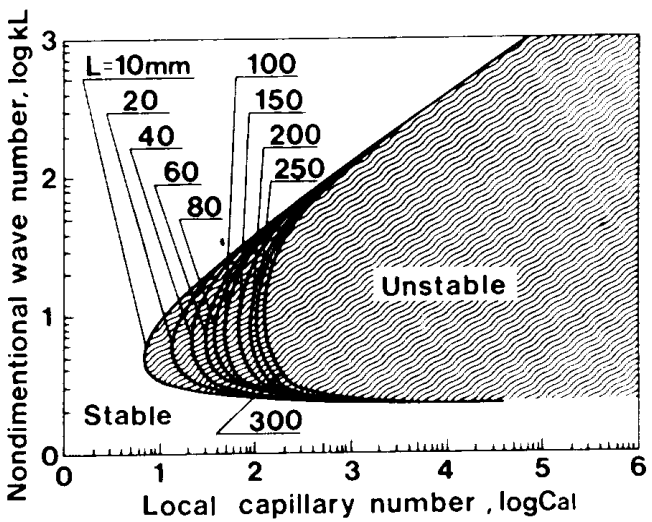

$\left(T=21.2 \mathrm{~m} \cdot \mathrm{N} / \mathrm{m}, \quad h=1.02 \mathrm{~Pa} \cdot \mathrm{s}, \quad l_{h}=1.0 \mathrm{~mm} / \mathrm{min}, h_{1}=0.5\right.$ $\mathrm{mm}, r_{1}=1.0 \mathrm{~mm}, L=10,20.40,60,80,100,150,200,250$. $300 \mathrm{~mm}$ )

図 4 板の長さ $L$ 変えた場合の中立安定曲線と無次元 波数との関係

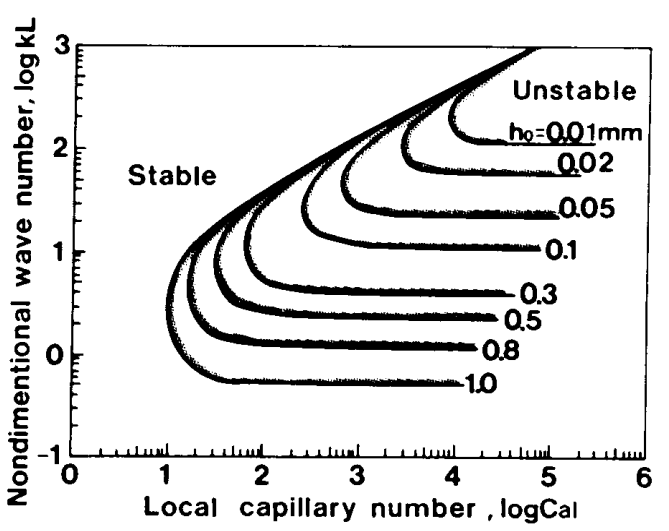

$\left(x_{1}=1.0 \mathrm{~mm}, \quad T=21.2 \mathrm{~m} \cdot N \mathrm{~m}, \quad y=1.02 \mathrm{~Pa} \cdot \mathrm{s}, \quad Y=1.0\right.$ $\mathrm{mm} / \mathrm{min}, L=60 \mathrm{~mm}, h_{4_{1}}=0.01 \sim 1.0 \mathrm{~mm}$ )

図 5 板の初期すき間 $h_{0}$ を変えた場合の中立安定曲線と 無次元波数との関保 
板の傾斜角の $1 / 3$ 以上であると自由表面が乱れる可能 性があることを意味する。

㛜密に無次元波数の臨界值を求めるためには、式 (22)をkで微分し，それを零とする。

$$
\begin{gathered}
\frac{\pi}{2} k L^{2}\left(\frac{I_{2} L}{I_{1}}+\frac{V_{s} L}{U_{x} h_{1}}-\frac{h_{0}}{h_{1}}\right)-\left(\frac{\pi}{4} k^{2} L^{2}+\frac{2 h_{0} L}{h_{1}{ }^{2}}\right) \\
\quad \times\left(\begin{array}{c}
V_{s} L \\
U_{x} h_{1}
\end{array}-\frac{h_{0}}{h_{1}}\right) \frac{I_{2} L}{I_{1}} \frac{d}{d K}\left(\frac{I_{1}}{I_{2} L}\right)=0 \cdots \cdots(25)
\end{gathered}
$$

この式は，無限級数を含む非線形方程式であるが, 前述した図から実数の極値はつつであり，その值は二 ュートン法捛よび繰返し代入法で求めることができ る。しかし、これは害際に計算する必要はなく、臨界局 所キャピラリ数と臨界波数は次節で示す式(26)の線上: を動く.

$2 \cdot 5$ 最大成長速度の乱れ 次に， $\omega$ を最大にす る波数の条件により局所キャピラリ数と波数の関係を 導 式が得的る。

$$
C a_{l}=\frac{\pi}{48}\left\{(k L)^{2}+\frac{2 h_{0} L}{h_{1}{ }^{2}}+\frac{2(k L)^{2}}{k-\frac{I_{1}}{I_{2}} \frac{d}{d k}\left(\frac{I_{2}}{I_{1}}\right)}\right\}
$$

この式は，局所キャピラリ数 $C a_{l}$ と乱れ0)波長 $\lambda 0$ 関倸であり，波長が短くなると第 1 項月に対して第 2 項月は無視でき，さらに第3 項目の分母はほほ1にな るため簡単な式に变形できる。その時, 波長は次式で 表すことができる。

$$
\lambda=\frac{L \pi^{3 / 2}}{2 \sqrt{C a_{l}}}
$$

ところで, 前述した臨界波長と臨界局所キャビラリ数 は，式(26)で寺えられる線上を移動する。このことは， 式(18)在 $k$ で微分する際，C $C a_{1}=C a_{\text {stat }}$ 上 $\partial C a_{\text {stab }} / \partial k$ $=0$ の関係を考慮することにより谷易に示すことがで きる。

$2 \cdot 6$ 実験との比較 乱れの無次元波数 $k I .0$ 来 験結果を中立安全曲線の式(21)(実線)扔上び式(26)

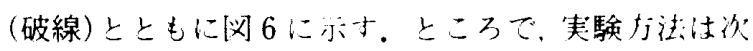

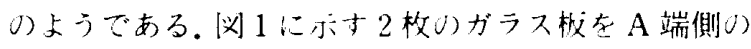
初期寸き間 $h_{0}$ を $0.3,0.5,0.75,1.05 \mathrm{~mm}, \mathrm{~B}$ 端側在 閉じて，板の傾きを洞走したまま。定速度 $V$ 。

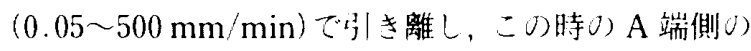

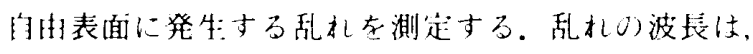
最初に月視により確認できたときU值である。この汹

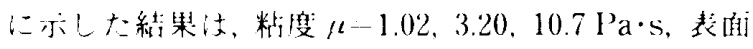

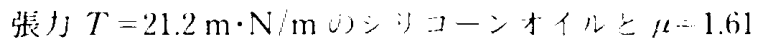

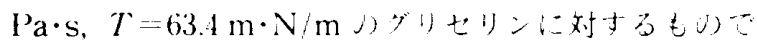

ある、なお，図中の赛験点に対する局所キャピラリ数 は，実験での波長の測走位置の $x$ 座標における よび速度を数值計算により求め,局所キャピラリ数の 定義式 (20)により求めた。図中には，h力が $0.3 \mathrm{~mm}$ 上 $1.05 \mathrm{~mm} の$ 場合の乱れを測定した位置における代表 的な理論計算結果を示しておいたが，これ以外の寸き 間に扮ける理論曲線は図に流した曲線の間にある。

この図で寒験における自由表面の乱れは，中立安定 曲線よりもドすなわち不㚣定領域で発生しており, 乱 れの成言速度が最大の条件で得られた式(26)の近傍に ある。前報 ${ }^{(19)}$ における計算結果と実験結果の差は，局 所キャヒララ数を用いることにより説明できる。また， この図から式(26)活乱れの発生:条件の一部を満たして いるだけであり，無次元波数が小さい(波長が衰い)領 域では安起領域にあることもわかる。これらのことか ら，メニスカスの移動速度を羘いた局所キャピラリ数 在用いれば，自由表面に発生する乱机に関する契験結 果は説明することができると考えられる。

\section{3. 結論}

本論文は、傾斜斗极間り薄い与き間に粘性流体在人

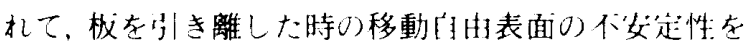
論じたものである。その紋果をまとめると次ひように なる。

（1）従来のキャビラリ数に対応して同所キャビラ リ数を新たに提案して，文の数上小市安定曲線抢よび 乱れの波数の関係式在解析的に求め，尖験と比較した 結果、本研究で求ぬた式に上り契験結果を上く説明で きるとがかかた。

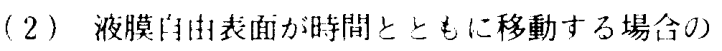

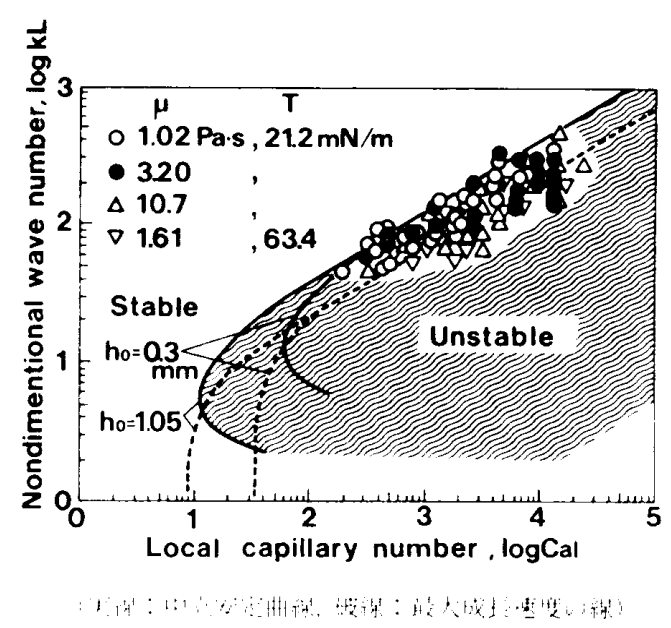

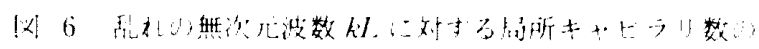

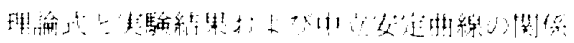


中立安定曲線の変化を調べた。その結果, 移動ととも にその曲線は司所キャビラリ数の大きいほうに移動す ることがわかった。

（3）傾斜平板の傾斜角を小さく寸ると，臨界局所 キャビラリ数抢よび無次元臨界波数は大きくなる。こ れ在通常のキャピラリ数の定義で考えると, 自由表面 汉傾斜角の $1 / 3$ 以上:のキャピラリ数で，乱机る可能性 があることがれかった。

\section{文献}

$1)$ Carter. (i. C. and Savage, M. I), Math. Fngr. Ind., 1 1987 (19395.

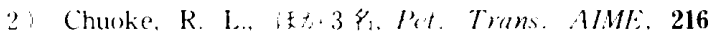
$19591,18 \times 194$

3) I)almaz, (;., Trans. ASME. J. Lab. Torh., 102 1980), $\$ 66+4 \pi \%$.

4) McEwan, A. I), and Taykor, (;. I., J. Fluid Merh, 26 (1966), 115

5) Nittmann, J.. I)accord, ( $x$, and Stanley; H. F.. Nature,
314 (1985), 141-144

(6) Park. C. W. and Homsy. (;. M., J. Fluid Mech. 139 (1984). 291-308.

(i) Park. C. W.. Gorell. S. and Homsy, (i. M., J. Fluid Merh., 141 (1984), 257-287.

(8) Pearson. J. R. A., J. Fluid Mech., 11 (1960), 481-500.

(9) Pitts. E. and (ireiller. J., J. Fluid Mcch.. 11(1961), 33 -50 .

(10) Reinelt, D. A., J. Fluid Mech., 183(1987), 219234.

(11) Saffman, P. (;. and Taylor, (i. I., Proc. R. Six . Lond.. Ser. A. $245(1958)$. $312 \cdot 329$

(12) Saffman, P. (i., J. Fluid Mech., 173 1986), 73-94.

(13) Savage, M. D., J. Am. Inst. (hem. ling., 30-6(1984). 999-1002.

(14) Savage, M. D.. J. Fluid Mech., 80(1977), 743756

(15)文献(14) 757767 -

(16) Savage. M. D.. J. Fluid Mech.. 117 (1982), 443-455.

(17) Tabeling. P., Zocchi. (;. and Libchaber, A., J. Fluid Mech. 177(1987), 67-82.

(18) Taylor, (i. I., J. Fluid Mech., 10(1961), 161165.

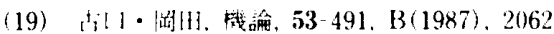

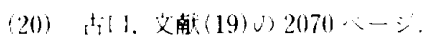

\section{[質問] 長谷川 英治 (慶伈義熟大学理I:学部)}

白所キャピラリ数をもとに臨界条件を求めていくと よいということが述心ららている。しかし，その中に 治前毛つて指走できない界面の移動速度 $U_{x}$ が入って いる。そこで，一つの提案なのだが，この問題には $\sigma$, $\mu, \rho, h_{0}, L, V_{s}$ なる前毛つて指定できる量があるから， 例之代ここれらり：つの無次元バラメータ， $\mu\left(V_{s} / \sigma\right) \cdot\left(L / h_{0}\right)^{2}, V_{s} h_{0} /(\mu / \rho), h_{0} / L$ 在作ることができ る.したがって, 臨界值を $\mu\left(V_{s} / \sigma\right)\left(L / h_{0}\right)^{2}=$ $f\left(V_{s} h_{0} /(\mu / \rho), h_{0} / L\right)$ のよに示してはどうかという ことである。このようなキャピラリ数が適切である理 由门一つは、 $u$ はこの問題では大体 $\left(L / h_{0}\right) V_{s}$ の程度 となっているから, 粘性力 $\int_{0}^{l} \mu \frac{\partial u}{\partial z} d x \sim \mu \frac{\left(L / h_{o}\right) V_{s}}{h_{o}} L$ 上表面張力による力 $\int_{0}^{h} \frac{\sigma}{h} d z \sim \sigma$ 上の比がこのキャピ ラリ数上な゙っており，このバランスの上で系の安起不 安定が決め的机るものと考えられるためである。ご意 見を挹きかせ願いたい。

(回答〕有意義なご提案に感謝する。キャピラリ 数を前もつて字えることができる量で定義したほうが 適当ではないかよのご意見であるが，そのキャピラリ 数に関して，著者らは質問者と同様な考えで，前報(19) では $\mu V_{s} / T\left(L / h_{0}\right)^{3}$ で定義した。そのときの解析は液 膜が板端部にある場合のものであった。それに対して
本論文では新たに局所キャピラリ数を $\mu U_{x} / T\left(L / h_{1}\right)^{2}$ で定義し、これを用いて実験結果を整理した結果, 理 論と契験はよく一致したことを報告した。この定義に 嗍いられている $U_{x}$ は本論文では， $U_{x}=-\left(V_{s} x_{1} / h_{1}\right.$ $\left.+C_{1} / 12 \mu h_{1}\right)$ を㯰き換えたものであり、数值計算ある いは丰験により求める必要がある。

ところで，質問者の提案に従って，中立安足曲線の 理論式を求めると，次式が得られる。

$$
\begin{aligned}
& \frac{\mu V_{s}}{T}\left(\frac{L}{h_{1}}\right)^{3}
\end{aligned}
$$

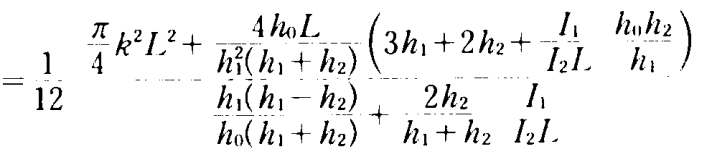

な扔、この式でキャピラリ数の定義は $\mu V_{s} / T\left(L / h_{1}\right)^{3}$ とした。上式では図 30 ようにキャビラり数り增大上 ともに中立安定曲線汶 1 本にまとまらず，液膜り厚き に忘じて曲線が描ける。 また, 式(23)に相当する臨界 キャピラリ数は $h_{0}^{2} L\left(3 h_{1}+2 h_{2}\right) / h_{1}^{3}\left(h_{1}-h_{2}\right) て ゙, V_{s}$ が $T / \mu h_{0}^{2}\left(3 h_{1}+2 h_{2}\right) /\left(h_{1}-h_{2}\right)$ 以上の速度で自由表現が乱 れる可能性があることがわかる. 式(26)の乱れの成長 速度最大の条件式は，次式のように表される。

$$
\frac{\mu V_{s}}{T}\left(\begin{array}{l}
L \\
h_{1}
\end{array}\right)^{3}=\frac{h_{0}\left(h_{1}+h_{2}\right)}{12 h_{1}\left(h_{1}-h_{2}\right)}
$$




$$
\times\left[\frac{\pi}{4} k^{2} L^{2}+\frac{4 h_{0} L\left(3 h_{1}+2 h_{2}\right)}{h_{1}^{2}\left(h_{1}+h_{2}\right)}+\frac{\frac{\pi(k L)^{2}}{2}}{k \frac{I_{1}}{I_{2}}-\frac{d}{d k}\left(\frac{I_{2}}{I_{1}}\right)}\right]
$$

この式は, 前述した式と同様に液膜の厚さに応じて異 なるキャピラリ数と乱れの波数の関倸を与えるため,
乱れの実験結果を統一的に整理するには適当とは思わ れない。系の安定性を論ずるにはどのようなキャピラ り数を用いても叮能であるが，実験結果を総合的に整 理する場合には，本論文て提案したキャピラり数のほ うが適寸ると考文る。 